\section{$1 \mathrm{G0900}$}

\author{
ジアセチレン脂質ポリマー化を用いた二分子膜の固 \\ 体表面上での微細パターン化 \\ ○森垣 憲一(産総研)
}

平滑な固体表而上に吸着した脂質二分子膜 (substrate supported planar lipid bilayer: SPB) は、生体膜を模した人、膜系として近年注 目されている。SPBの特徴は、固体に支持されることによる膜の安 定化と電気化学的 ·光学的界面分析手法を利用できる点にある。本 研究は、基板上で微紐化加Tすることが可能であるというSPBのも うひとつの特徵を活かし高度に集積された人、生体膜を構築するた め、脂質の光重合反応を用いた二分子膜のパターン化手法を開発し た。Langmuir-Blodgett/ Langmuir- Scharfer 法を用いてジアセチレ ン光重合基老持つリン脂質 1,2-bis(10,12-tricosadiynoyl)-sn-glycero-3phosphocholine二分子膜をガラス基板上に吸着し、膜の一部をマスク で保護しながら紫外光 $(254 \mathrm{~nm})$ 照射することにより二分子膜を局所 的に光重合した。保護されたモノマー膜を有機溶媒で選択的に除去す ると、ポリマー化した二分子膜のみが基板上に残る。そのポリマー膜 を鋳型としてその間の空白部に新しい脂質二分子膜（卵黄より抽出し たレシチン： egg-PC) を vesicle fusion method を用い挿入した。パ ターン化されたポりマー二分子膜によって定められた空間に組み込ま れた egg-PCの二分子膜が生体膜に類似した膜流動性を保持している ことは、膜中に含まれる蛍光標識分子 (NBD-PE) を局所的に強い照 射光を用いて消光し、蛍光が脂質分子の水平拡散で回復する過程を観 察することで確認された。以上の結果より、生体膜を模した脂質二分 子膜をポリマー膜の鋳型中に組み込むというパターン化手法が原理的 に可能であることが示された。(参照文献) Morigaki, K.; Baumgart, T.; Offenhässer, A; Knoll, W. Angew. Chem. Int. Ed. Engl. 2001, 40), 172-174.

K.Morigaki : Patterning solid-supported lipid bilayer mombranes by lithgraphic polymerization of a diacetylene lipid

\section{$1 \mathrm{G} 0930$}

\section{直鎖及び分岐鎖を持つ脂質二重層膜の構造の比較：分}

子動力学シミュレーションによる研究

○篠田 渉 1 、三上益弘 ${ }^{1}$ 、馬場照彦 ${ }^{2}$ 、羽藤 正勝 ${ }^{2}$ (1産総 研・計算科学、2 産総研・ナノテク)

メチル分岐のあるフィタニル鎖を持つ脂質分子が形成する二重層膜は 分岐のない膜に比べて安定性が高く,プロトンなどの透過性が低いこ の特性を利用した合成糖脂質膜にはバイオテクノロジー分野における 機能性材料としての有用性が期待されている.しかし.メチル分岐の存 在が膜の性質にどのような機構で影響を及ぼすのかについて,その分 子論的な知見はそしい，そこで本研究では, 疎水鎖が直鎖の DPPC と フィタニル鎖の DPhPCが、それぞれ形成する....重層膜の分子動力学 (MD) シミュレーションを行い, 構造及びダイナミクスの比較を行っ た.MD は等温 $(323 \mathrm{~K})$ 等圧 $(0.1 \mathrm{MPa})$ で $2.5 \mathrm{~ns}$ の計算をそれぞれ行っ た. 疎水鎖の配向分布では,いずれの脂質も膜垂直方向への配向が最も 多くみられ、DPhPC 分子は上り広い分布を示した. 疎水鎖のオーダー

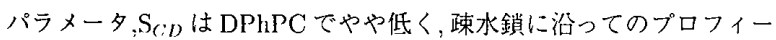
ルは分岐の位置において不連続に変化した.これは分岐位置で, 主鎖 二而角の gauche 構造の増加と関連するものと考えられる。百角界性 化速度は DPhPC でより漣く,アルキル鎖中央部で約う倍もの差が見 られた．また，脂質分子の重心に対する膜面内でのボロノイ解析から， $\mathrm{DPhPC}$ は分子の配列秩序がより高く，膜而積採らぎの時定数がより 長いことがわかった，以上のことから，分岐鎖を持つ脂質分子では、ア ルキル鎖の局所的秩序は低くなるが分子の膜面内における並びはより 規則的で, 運動性が低く, 摇らぎよる膜の破れや poreの形成は起こ りにくいものと推測される.また，膜柾水領域における (水分子に相当 する大きさを持つ) 空隙の存在確率分布の調査から,DPPCでは比較 的大きな空腙が見られるが,DPllPC では小さな空隙が分散して存在す ることがわかったこの結果は,プロトン透過において重要な役割を担 うと考えられる水分子ワイヤの生成確率が，メチル分岐の存在によっ て低下することを示唆するものである。

W. Shinoda, M. Mikami, T. Baba, and M. Hato: A comparison of straight- and branch-chained lipid bilayers for the static and dynamic properties: a molecular dynamies study.

\section{$1 \mathrm{G} 0915$}

水素化アモルファスシリコンと有機材料の接合によ る膜構造システムの試み

○須藤 純也 ${ }^{1}$ 、後藤 研滋 ${ }^{1}$ 、柴田 重樹 ${ }^{1}$ 、石丸 正 $^{1}$ 、伊原 学 3 、增本 博 ${ }^{2}$ 、後藤 孝 $^{2}$ 、过内 裕 ${ }^{1} \quad{ }^{1}$ 秋田大. 工学資源・材 料工、 2 東北大 · 金研、 3 東北大 ·多元研)

生体膜などに含まれる有機高分子と無機材料の接合した二次元的な 㞬間構造を持つ人、T的な膜構造システムを構築し、構成される元素や 薄膜、生体膜の構造と機能の間に有意な相亘作用が生じる可能性を模 索することを目的とする。無機材料側にはアモルファスシリコン、及 び水素化アモルファスシリコンを薄膜状に作製したものを用い、有機 材料にはバクテリオロドプシン蛋白の天然蛋白及び構成ペプチド、ア ントシアニン系色素を用いている。アモルファスシリコン、及び水素 化アモルファスシリコンの薄膜の作製を E C Rプラズマスパッタ法で 行なった。原子間力顕微鏡による像から 0.8 ナノメートル以下の凹凸 の極めて平坦な薄膜として作製できていることがわかった。作製条件 は、ターゲット基板間距離 $160 \mathrm{~mm}$ 、マイクロ波実効電力 $500 \mathrm{~W} 、 \mathrm{R}$ F 電源用実効電力 $500 \mathrm{~W}$ 、ガス流量 $27.8 \mathrm{SCCM}$ (アモルファスシリ コンの場合のアルゴンガス）などであった。有機高分子との接合、特 に生体高分子などの高機能の分子の単分子膜の接合、積層膜の作製に 適した条件を満たすものとして可能性を检討し始めている。バクテリ オロドプシン蛋白の場合、アモルファスシリコンの可視領域の光吸収 帯と重なる光吸収帯をもち、アモルファスシリコン、及び水素化アモ ルファスシリコンの薄膜に接合した場合、水素量によって異なる吸収 スペクトルを示すことが解析の結果わかってきた。アモルファスシリ コンとペプチド内の水素との間の相互作用がアモルファスシリコンの 水素化の量に影響されるものと考えられるが、現在検討中である。

J.Suto, K.Goto, S.Shibatam, T.Ishimaru, M.Ihara, H.Masumoto, T.Goto, Y.Tsujinchi : An attempt for thin film structural systems of organic materials jointed with hydrogenated amorphous silicon

\section{$1 \mathrm{G} 0945$}

$$
\begin{aligned}
& \text { 生体膜及び膜タンパク質の分子動力学シミュレーショ } \\
& \text { シプロトコル } \\
& \text { ○橋戸 公則、池口 満德、木寺詔紀（横市大院・総合理学） }
\end{aligned}
$$

生体膜と膜タンパク質の物性・機能を解析するためには、分子動力学シ ミュレーションが有効な手段である。しかし、生体膜や膜環境中の膜夕 ンパク質の系は、従来の水溶性タンパク質の系とは異なり異方的な系 であるため、新たなシミュレーションプロトコルが必要である。そこで 本研究では、アンサンブル、境界条件などの各種条件を探索し、より 現実を反映した生体膜及び膜タンパク質の分子シミュレーションプロ トコルを確立することを目的とした。まず、生体膜を構成する脂質分 子は、飽和脂肪酸として dimyristoilphosphatidylchorine(DMPC) 老、 また不飽和脂肪酸として palmytoyloleoilphosphatidylchorin(POPC) を選んだ。力場パラメー多はCHARMN27を用い、時間積分には工 ネルギー保存精度の高い部分剛体時間反転分子動力学法を用いた。静 電気力の計算にはPME 法を使用した。プログラムは当研究室で開発 している MARBLEを用いた。条件検討として等温等压 (NPT) アン サンブル、等温等压等表面積 (NPAT) アンサンブル、また、セルの形 状が直方体を保って変化する通常の方法のほかに、七ルの各軸間の角 度が変化し、平行六而体に変形することができるParrinello-Rahman 法を試した。order parameter、電子密度マップの実験值と比較した ところ、寸べての系で比較的良好なデータが得られたが、NPT アン サンブルでは表面積が実験値より若干低い值を示す傾向にあり、表面 積を実験值に固定するNPAT アンサンブルが、order parameter の実 験值と最もよく一致を示した。続いて、このプロトコルで得られた膜 を用いアクアポリンのシミュレーションを行った。この詳細は当日議 論する予定である。

M.Hashido, M.Ikeguchi, A.Kidera : Protocol of molecular dynamics simulation for lipid bilavers and membrane proteins 